\title{
Applying Value Engineering Technique Using Building Information Modeling at Underground Metro Station
}

\author{
Samir Abdelfatah', Mohamed Abdel-Hamid², Abdel-Aziz Ahmed ${ }^{3}$ \\ ${ }^{1}$ (Department of Civil Engineering, Faculty of Engineering / El Azhar University, Egypt) \\ ${ }^{2}$ (Department of Civil Engineering, Faculty of Engineering at Shobra / Benha University, Egypt) \\ ${ }^{1}$ (Department of Civil Engineering, Faculty of Engineering / El Azhar University, Egypt)
}

\begin{abstract}
:
Construction sectors play a major role in developing Egyptian country; moreover the cost is the keyword at the construction cycle. This study presents the basis of implementation of Value Engineering (VE) at each stage that can be used to reduce the total cost for the construction project. Value Engineering improves the product cost by reducing the unnecessary costs associated with the product. In this paper Value engineering processes have been explained, on the other hand a case study for constructing the Greater Cairo Metro (Line 3-Phase 3) has been discussed and an analysis has been done by this process to reach the final optimization. In December 2016, The contractor signed contract with the client at the same prices of the previous phase which issued in 2013, so that he try to implement Value engineering technique to reduce the cost of execution phase considering the same function of the project. The application of VE is must be done parallel with respecting and checking if there any obstacles for the new design which may affect the routes of other activities like (MEP works, rails activity or mechanical works). This condition will be clear if the tool like Building Information Modeling technique (BIM) is used which is the one of its main function to preview any clash might happened with different activities. At the final, it is concluded that the cost decreased by $23 \%$ of the total price of typical slabs and $1.7 \%$ of the overall contract amount without changing the basic purposes of the element.
\end{abstract}

Keywords: value engineering technique; building information modeling; infrastructure projects; cost control

\section{INTRODUCTION}

$\mathrm{VE}$ is a technique directed at analyzing the function of all projects/processes items for the reason of attaining their essential purposes at minimum cost suitable with entailed operation, feature, and function. The application of the Value Engineering technique improves integration of performance, feature, efficiency, or other needed functions. As costs can be measured easily, cost decrease is frequently believed of as the main criteria for application of Value Engineering. But, the main purpose of Value Engineering is value enhancement, and that might not be outcome in a quick decrease of cost. Value engineering regularly takes place after a design phase, even the best time to do it actually is before phase of design. A value analysis is proceeding in accordance with practitioners or topic matter experts gather together to implement the value methodology. The standard job plan of VE consists of 6 phases, these phases are:

- Gathering project information and understanding its main goals.

- Identifying the functions of the project.

- Proposing alternative solutions which accomplish the functions and add value.

- Reducing the ideas to a short list that can be executed.

- Development the alternatives into applicable and visible plans.

- Presentation the results to all stakeholders.

The research aims to propose for VE using a visual model (BIM) to gather input information for the appraisal model and to assist in the visual evaluation process for decision makers, designers/owners and members of VE teams to evaluate and compare various alternatives of a project based on the predefined criteria (focused mainly on the project cost) by Identifying the weight criteria related to each alternative. One of the greatest serious stages in the use of $\mathrm{VE}$ is the assessment of new solutions. The outline will be settled and planned to aid The Value Engineering team for better evaluation and ranking the various construction project items options using BIM (building information modeling) as the clash detection is one of the main features of BIM (Irin A., 2019 ). In additional to that; a case study will be used to employ the suggested outline application and determine its effectiveness in the assessment of using VE by means of questionnaire and interview with the different stakeholders related to the construction phase.

\section{LITERATURE REVIEW}

The theory of VE has subsisted for more than 50 years (Rich, 2000). It had its source through Second World War at Common Electric when improvement was needed because of resource lacks (Miles, L. D., 1972). Some important resources were tough to attain and several replacements had to be created. Harry Erolicker, a vice head, detected that lots of periods these varies caused in drop costs and better results. 
International Journal of Engineering Research and Technology. ISSN 0974-3154, Volume 13, Number 7 (2020), pp. 1555-1561

(C) International Research Publication House. https://dx.doi.org/10.37624/IJERT/13.7.2020.1555-1561

This urged him to search for a method to develop an outcomes value. He gave Lawrence D., an engineer, the task of discovering a further operative method to enhance outcome value (Attarde, 2016). During 1947, Miles and his crew improved a steadily technique named Value Analysis (VA), to examine outcome cost and function to decrease unnecessary costs.

\section{VALUE ENGINEERING APPLICABILITY}

Referring to Attarde (2016), the Value Engineering procedure can be used where cost and/or working development is estimated. That enhancement can be established in terms of financial features and/or other analytical issues such as efficiency, schedule, environmental influence, and stability. Table (1) displays the key issues that influence applicability of VE practice found by many studies.

Table 1: Factors Affecting VE Applicability

\begin{tabular}{|c|c|c|}
\hline No & Features & References \\
\hline 1 & Absence of local guidelines and information & (Ali, 2013; Al-Yousefi, 2011; Senay, 2013) \\
\hline 2 & Lack of knowledge and practices & (Ali, 2013; Amir, 2009; Al-Yousefi, 2011) \\
\hline 3 & Interruption to normal work schedule & (Ali, 2013; Senay, 2013) \\
\hline 4 & Change in owners' requirements & (Amir, 2009; Ali, 2013; Al-Yousefi, 2011) \\
\hline 5 & Clash of goals by various project participants & (Senay, 2013) \\
\hline 6 & Outdated standards and specifications & (Al-Yousefi, 2011; Senay, 2013) \\
\hline 7 & Habitual thinking and negative attitude & (Amir, 2009; Ali, 2013) \\
\hline 8 & Shortage of culture to agree the modification & (Ali, 2013; Senay, 2013) \\
\hline 9 & Over-design and overestimating & (Al-Yousefi, 2011; Senay, 2013) \\
\hline 10 & Shortage of communication & (Ali, 2013; Al-Yousefi, 2011) \\
\hline 11 & Lack of inventive ideas & (Al-Yousefi, 2011; Senay, 2013) \\
\hline 12 & The significance of inserting VE in the Agreement & (Amir, 2009; Attard, 2016; Chi-Sung In, 2009) \\
\hline 13 & Essential of the existence of a VE qualified People in the team & (Ali, 2013; Al-Yousefi, 2011) \\
\hline 14 & The need of delivering VE teaching occasions for specialists & (Ali, 2013; Senay, 2013) \\
\hline 15 & The necessity of enhancing the communication for engineers & (Amir, 2009; Ali, 2013) \\
\hline 16 & the occurrence of variety of purchasing methods for projects & (Ali, 2013; Al-Yousefi, 2011) \\
\hline 17 & The essential of creating owners further wanting of VE & (Ali, 2013; Senay, 2013) \\
\hline 18 & Reducing Construction Production Costs & (Ali, 2013; Chavan A., 2013) \\
\hline 19 & Finishing the Job before Time Schedule & (Ali, 2013; Senay, 2013) \\
\hline 20 & Quality Improvement and Correction & (Ali, 2013; Amir, 2009) \\
\hline 21 & Reduction the errors in project drawings to least & (Amir,2009; Al-Yousefi,2011; Senay,2013) \\
\hline
\end{tabular}

\section{BUILDING INFORMATION MODELING (BIM)}

Building Information Modeling (BIM) is one of the greatest talented improvements in the construction sectors. Building Information Modeling placed the project in a computergenerated state. With Building Information Modeling knowledge, a detailed effective prototype of a building is arranged. When finished, the computer- generated form includes certain geometry and applicable records required to verify the construction and purchasing actions needed to understand the building (Salman A., 2008). BIM helps to provide an insight for construction project planning, cost and time process. Using this technique as combinations between applications of BIM and scheduling may include animation for the execution phase at construction projects in addition to, time information already linked to three-dimensional form (Srimathi S., 2017). Furthermore, BIM is mainly a 3D numerical image of a project and its fundamental features. It is created of wise project elements which contains information features and parametric guidelines for every item. This keeps a lot of engineer's time since every view is organized during the built-in information of the model. BIM is "a digital representation of physical and functional characteristics of a facility and a shared knowledge resource for information about a facility forming a reliable basis for decisions during its life-cycle; defined as existing from earliest conception to demolition" (building SMART, 2012). BIM is the procedure of computer-generated model through project life cycle. It is a phase to distribute data among building stakeholders (Cheng Z., 2016). 
International Journal of Engineering Research and Technology. ISSN 0974-3154, Volume 13, Number 7 (2020), pp. 1555-1561

(C) International Research Publication House. https://dx.doi.org/10.37624/IJERT/13.7.2020.1555-1561

\section{CASE STUDY}

The case study of this research is Maspero Underground Station, Line 3, and Phase 3. As mention before, the main contractor signed contract with the client at December 2016 with the same prices of the previous phase which issued at 2013, so that he try to use the Value Engineering technique to reduce the cost amount of execution phase considering keep the same function of the project. To avoid any intersected activities at the new design while applying the Value Engineering, Building Information Modeling technique was used. Cost assessment for the project under consideration is made by the consultant as in table (2). Pareto Analysis is used to identify the required major elements in the project. Four out of Fourteen items contain $77 \%$ of the total cost, in the other word $28 \%$ of the total items contain $77 \%$ of the total cost; this results agrees the rule of Pareto. Table (2) and Figure (1) show the summary of the cost weight for all project items.
Table 2: Cost estimation of different elements

\begin{tabular}{|l|l|l|c|c|}
\hline No & Item & Cost (LE) & $\begin{array}{c}\text { \% of the } \\
\text { Project cost }\end{array}$ & Notes \\
\hline 1 & Mobilization & $712,618.00$ & $0 \%$ & - \\
\hline 2 & Concretes works & $75,798,675.00$ & $43 \%$ & Selected \\
\hline 3 & Masonry works & $7,051,039.53$ & $4 \%$ & - \\
\hline 4 & Plastering works & $5,288,279.65$ & $3 \%$ & - \\
\hline 5 & $\begin{array}{l}\text { Tiles and Marble } \\
\text { works }\end{array}$ & $15,864,838.95$ & $9 \%$ & Selected \\
\hline 6 & Painting works & $1,642,709.98$ & $1 \%$ & - \\
\hline 7 & Wood works & $1,882,809.78$ & $1 \%$ & - \\
\hline 8 & Aluminum works & $10,576,559.30$ & $6 \%$ & - \\
\hline 9 & Steel works & $1,976,809.00$ & $1 \%$ & - \\
\hline 10 & $\begin{array}{l}\text { Complementary } \\
\text { works }\end{array}$ & $5,288,279.65$ & $3 \%$ & - \\
\hline 11 & Isolation Works & $1,976,810.76$ & $1 \%$ & - \\
\hline 12 & Outdoor works & $5,288,279.65$ & $3 \%$ & - \\
\hline 13 & Mechanical Works & $26,441,398.26$ & $15 \%$ & Selected \\
\hline 14 & Electrical works & $16,486,880.86$ & $10 \%$ & Selected \\
\hline
\end{tabular}

Concrete works LE 75798675.00

Plastering works LE 5288279.65

Painting works LE 1642709.98

Aluminum works LE 10576559.30

Complementary works LE 5288279.65

Outdoor works LE 5288279.65

$10 \% 0 \%$

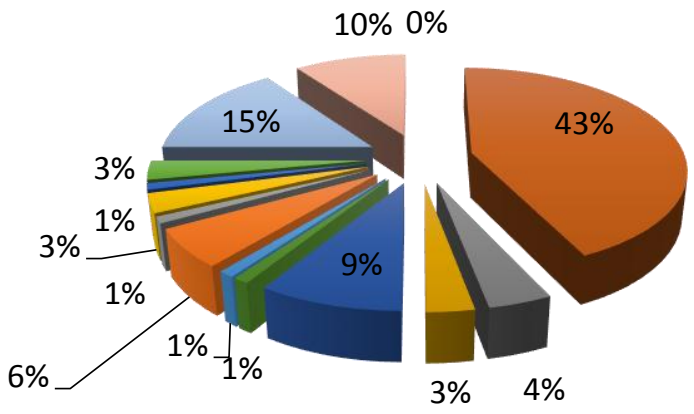

Figure 1: Summary of the cost weight for all project items

\section{APPLICATION OF VALUE ENGINEERING}

During information phase of value engineering technique, the team collected all needed information of specifications, standards, cost estimate and the client's necessities to certify right aware of the project objectives and specifications. After analyzing expenses model for the construction project, it was observed that the initial design would outcome with an entire expenses of (LE176,275,988) as shown in Table (2). Consequently to the Pareto law, the concrete work includes $43 \%$ of the entire cost; the value engineering team chooses this item.

In functional analysis phase, the VE team starts the workshop to analyze the existing design in terms of cost. The function analysis will help VE team for accurate judgment if it is either to redesign the structure elements, or to change the method of work for execution respecting the function.

In Estimation Phase, the value engineering crew seeking for the elements of the items significantly influences the total cost. A set of ideas were created to decrease the cost without influencing the fundamental purposes. After the examination for other options, the foundation most agreed alternative was captured to be operated using the Building Information Modeling tools. In this phase, the slab of Maspero station is chosen. The typical slabs, as shown in Figure (2), are designed 
with big thicknesses and with high steel ratios; therefore, the total cost of constructing the slabs is high. Constructing steel barrettes, as in shown in Figure (3), is proposed as the alternative design. The steel barrettes are composite column sections made of built up I-Beams and plates. These barrettes are hammered between the two sides of the diaphragm walls with the same height. This will significantly minimize the span of the slabs; accordingly, the thicknesses of the slabs will decrease and total cost will decrease as well.

Table (3) and tables $(4,5)$ show the two alternatives which are typical slabs construction and construction of slabs using the steel barrettes from the perspective of cost. Both alternatives are structurally acceptable and will satisfy and perform the function of the slabs. The total concrete cost for typical design is 50.553 Million LE, The total steel cost for typical design is 25.246 Million LE and total cost is 75.799 Million LE as shown in Table (3). The total concrete cost for alternative design is 33.83 Million LE, The total steel cost for alternative design is 12.96 Million LE, the cost of steel sections added for alternative design is 11.97 Million LE and total cost is 58.76 Million LE as shown in Tables $(4,5)$.

Table 3: Quantity and cost amount of concrete and steel reinforcement for ordinary design

\begin{tabular}{|l|c|c|c|c|c|c|c|c|c|c|}
\hline Items & $\begin{array}{c}\text { L. } \\
(\mathrm{m})\end{array}$ & $\begin{array}{c}\text { W. } \\
(\mathrm{m})\end{array}$ & $\begin{array}{c}\text { D. } \\
(\mathrm{m})\end{array}$ & $\begin{array}{c}\text { Total } \\
\text { Quant. } \\
\left(\mathrm{m}^{3}\right)\end{array}$ & $\begin{array}{c}\text { Concrete } \\
\text { Unit Rate } \\
\left(\mathrm{LE} / \mathrm{m}^{3}\right)\end{array}$ & $\begin{array}{c}\text { Concrete } \\
\text { Cost } \\
(\mathrm{M} . \mathrm{LE})\end{array}$ & $\begin{array}{c}\text { Steel } \\
\text { Ratio } \\
\left(\mathrm{kg} / \mathrm{m}^{3}\right)\end{array}$ & $\begin{array}{c}\text { Steel } \\
\text { Quant. } \\
(\text { ton })\end{array}$ & $\begin{array}{c}\text { Steel } \\
\text { Unit Rate } \\
(\text { LE/ton })\end{array}$ & $\begin{array}{c}\text { Steel } \\
\text { Cost } \\
(\mathrm{M} . \mathrm{LE})\end{array}$ \\
\hline Roof Slab & 150 & 20.5 & 1.5 & 4624 & 4000 & 18.495 & 175 & 809.2 & 12000 & 9.710 \\
\hline Ticket Slab & 150 & 20.5 & 1.2 & 3699 & 4000 & 14.796 & 175 & 647.3 & 12000 & 7.768 \\
\hline Int. Slab & 150 & 20.5 & 1.4 & 4316 & 4000 & 17.262 & 150 & 647.3 & 12000 & 7.768 \\
\hline
\end{tabular}

Table 4: Quantity and cost amount of concrete and steel reinforcement for alternative design

\begin{tabular}{|l|c|c|c|c|c|c|c|c|c|c|}
\hline Items & $\begin{array}{c}\text { L. } \\
(\mathrm{m})\end{array}$ & $\begin{array}{c}\mathrm{W} . \\
(\mathrm{m})\end{array}$ & $\begin{array}{c}\mathrm{D} . \\
(\mathrm{m})\end{array}$ & $\begin{array}{c}\text { Total } \\
\text { Quant. } \\
\left(\mathrm{m}^{3}\right)\end{array}$ & $\begin{array}{c}\text { Concrete } \\
\text { Unit Rate } \\
\left(\mathrm{LE} / \mathrm{m}^{3}\right)\end{array}$ & $\begin{array}{c}\text { Concrete } \\
\text { Cost } \\
(\mathrm{M} . \mathrm{LE})\end{array}$ & $\begin{array}{c}\text { Steel } \\
\text { Ratio } \\
\left(\mathrm{kg} / \mathrm{m}^{3}\right)\end{array}$ & $\begin{array}{c}\text { Steel } \\
\text { Quant. } \\
(\text { ton })\end{array}$ & $\begin{array}{c}\text { Steel } \\
\text { Unit Rate } \\
(\mathrm{LE} / \mathrm{ton})\end{array}$ & $\begin{array}{c}\text { Steel } \\
\text { Cost } \\
(\mathrm{M} . \mathrm{LE})\end{array}$ \\
\hline Roof Slab & 150 & 20.5 & 0.9 & 2774 & 4000 & 11.1 & 145 & 402.3 & 12000 & 4.83 \\
\hline Ticket Slab & 150 & 20.5 & 0.8 & 2466 & 4000 & 9.86 & 145 & 357.6 & 12000 & 4.29 \\
\hline Int. Slab & 150 & 20.5 & 0.8 & 2466 & 4000 & 9.86 & 130 & 320.6 & 12000 & 3.85 \\
\hline $\begin{array}{l}\text { Columns } \\
(34 \text { PCs })\end{array}$ & 1.48 & 0.68 & 19.5 & 667 & 4500 & 3.00 & N/A & N/A & N/A & N/A \\
\hline
\end{tabular}

Table 5: Quantity and cost amount of steel sections added for alternative design

\begin{tabular}{|l|c|c|c|c|c|c|c|}
\hline Item & No. & No I-Beams per barrettes & $\begin{array}{c}\text { Depth } \\
(\mathrm{m})\end{array}$ & $\begin{array}{c}\text { Weight/Item } \\
(\text { ton })\end{array}$ & $\begin{array}{c}\text { Total Weight } \\
(\text { ton })\end{array}$ & $\begin{array}{c}\text { Unit rate } \\
\text { (LE/ton) }\end{array}$ & $\begin{array}{c}\text { Total cost } \\
(\mathrm{M} . \text { LE) }\end{array}$ \\
\hline Barrettes & 34 & 3 & 24.1 & 0.142 & 349.06 & 25000 & 8.73 \\
\hline Base plate & 680 & N/A & N/A & 0.165 & 112.2 & 25000 & 2.8 \\
\hline Studs & 24508 & N/A & N/A & 0.00072 & 17.646 & 25000 & 0.44 \\
\hline
\end{tabular}


The most significant stage in the using VE is the multiapproved appraisal of new choices in the speculative stage. Cost is one of the most necessary factors that plays a key role in the choice of the best option that performs greatest value added built on the measures applied in this procedure. As shown in the above-mentioned calculations, the slab thicknesses decreased by approximately $40 \%$. Moreover, the total cost of constructing slabs with steel barrettes is less that the total cost of constructing typical slabs by approximately 17 Million EGP as shown in Figure (4) which represents about $23 \%$ of the total price of typical slabs and $1.7 \%$ of the overall contract amount.

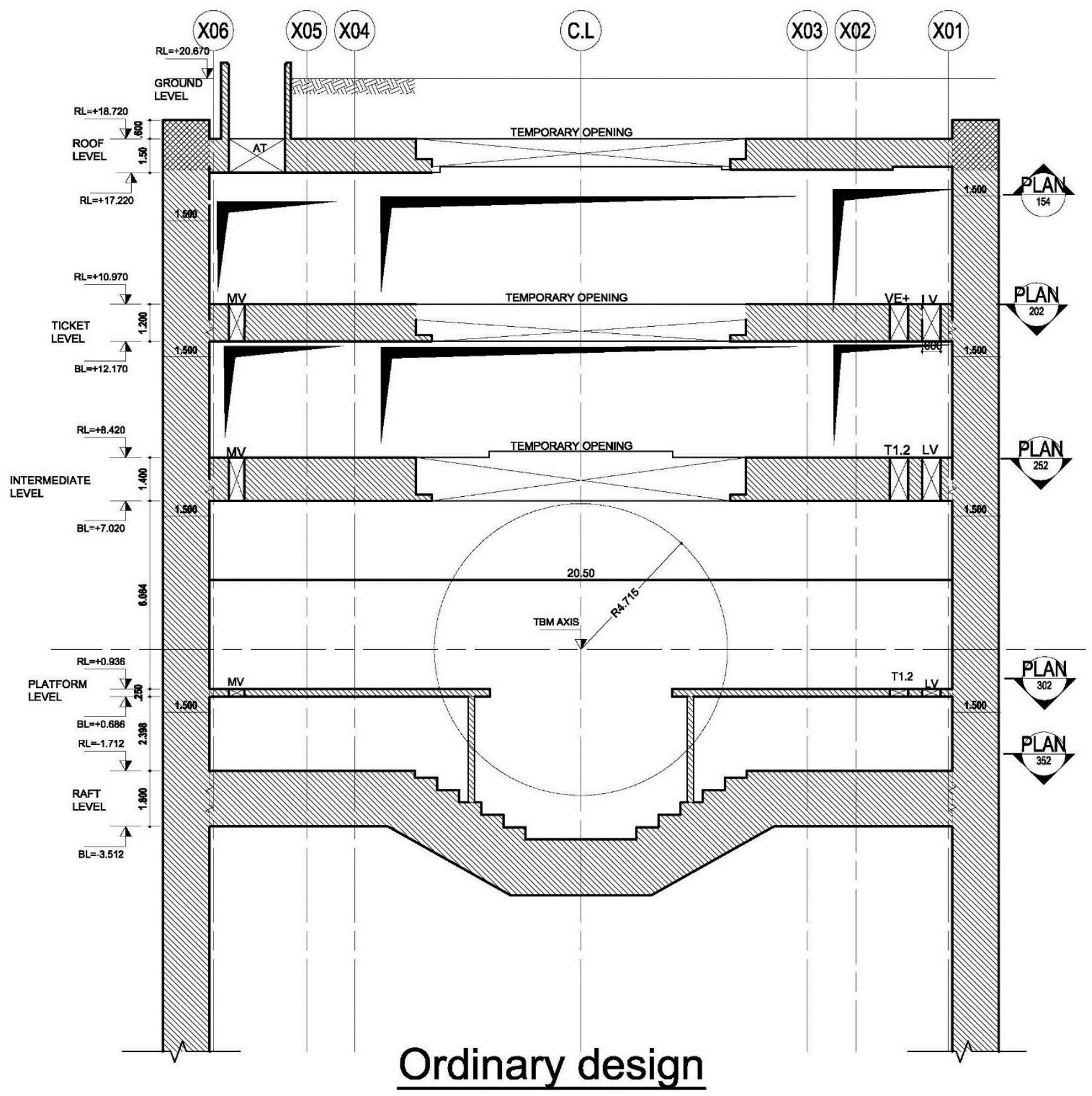

Figure 2: Cross section for ordinary design 


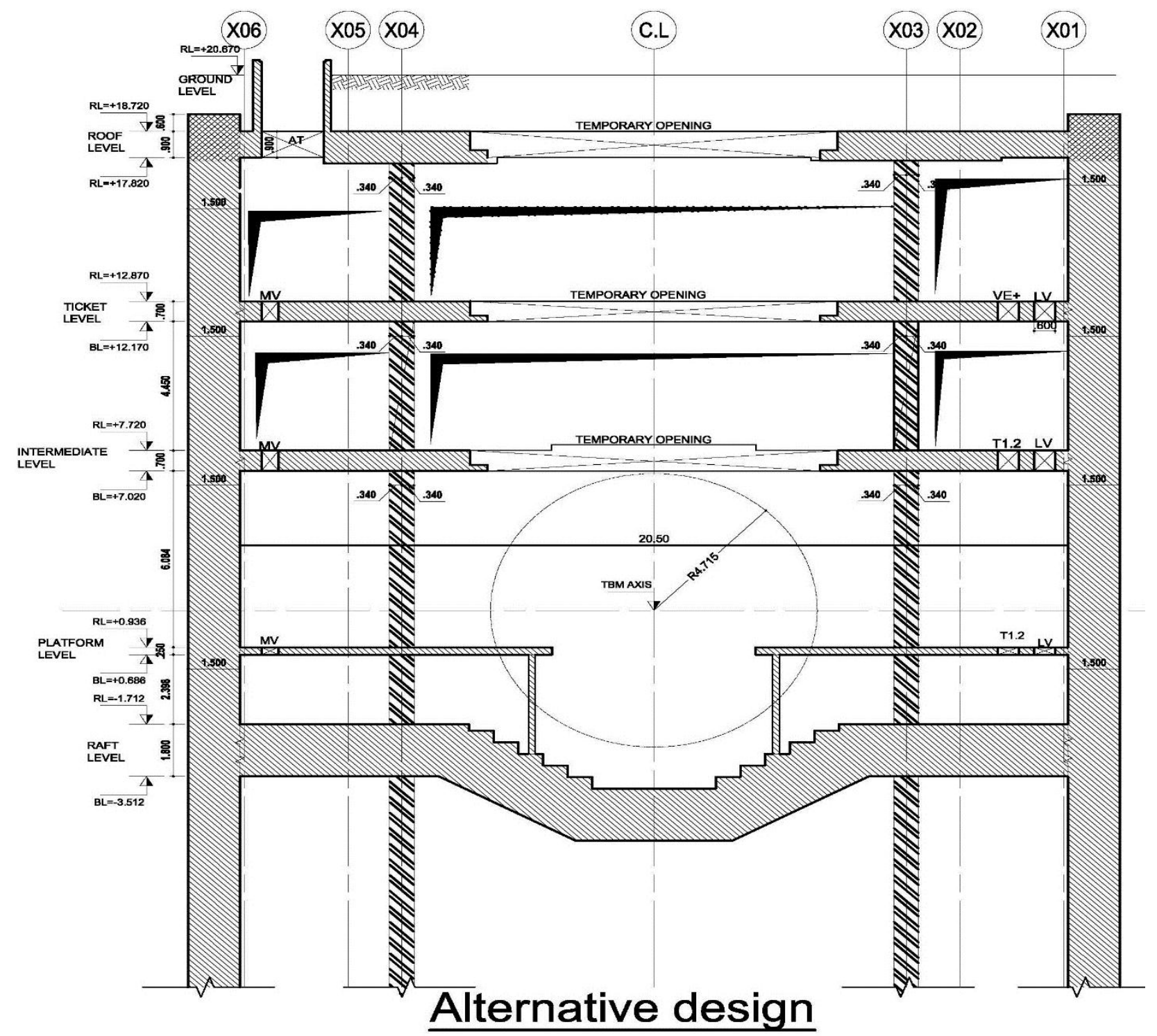

Figure 3: Cross section for alternative solution

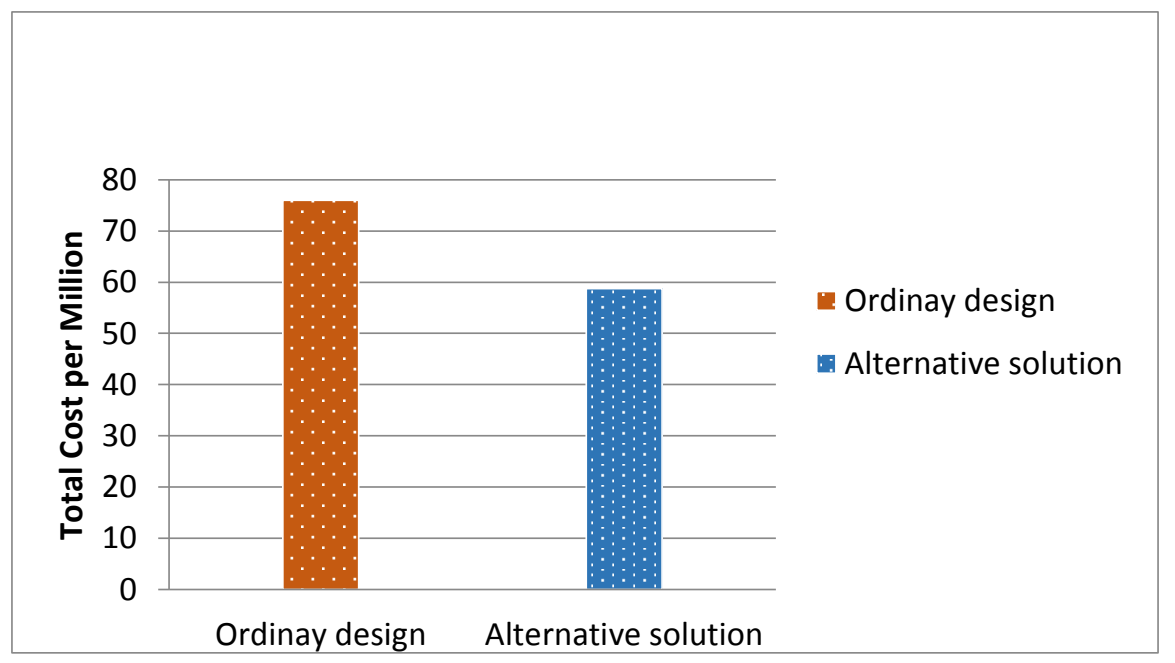

Figure 4: Compare between total costs before and after applying VE 
From the time perspective, the method of constructing slabs using steel barrettes will not affect the time schedule since the barrettes are hammered in parallel with the construction of diaphragm walls. This means that both methods will take the same construction time. However, the new method significantly decreased the thicknesses of slabs along with their steel ratios and will perform the same function of the typical slabs with lower costs. Therefore, the study strongly recommends the method in constructing the slabs of Maspero Underground Station. The Value Engineering team had overall analysis for the function of the last choice for alternatives which produced and applying by the team after using Value Engineering methodology therefore, they recommend replacing ordinary slab with tension piles (barrettes).

\section{CONCLUSION AND RECOMMENDATION}

VE produces proficiency and aids users to acquire numerous advantages. It suggests the point that employers of all phases could understand VE as assisting them work improved, and cost savings are further possible to be achieved by skilled users. In this paper by applying VE technique on Greater Cairo Metro (Line 3 - Phase 3) as a case study, the cost decreased by $23 \%$ of the total price of typical slabs and by $1.7 \%$ of the overall contract amount without influencing on the fundamental purposes of the products. Also, using BIM produces advantages to the construction sector. These advantages are: visual retrieve to construction project data, allows simple clash resolves, aid to schedule the construction project procedure, maintain to achieve the intricate costs and permit enhanced organization and well management.

Even though the helps model improve the supposition stage and valuation stage of the Value Engineering Job strategy, future researches can be prepared to enhance the application of the model and expand the suggested procedure. Several of the suggestions that can enhance the study as shown below:

- The outline is used to another case study; however, additional case studies can be guide to improved analysis the suggested outline and to discover its constraint in other various projects.

- The outline is limited for mega construction projects and it must be used in the normal construction building projects.

- The cost information measured for the case study considers the direct cost into account. Furthermore, life cycle cost should be involved in the future research.

\section{REFERENCES}

[1] Irin A. I., Anoop C. K. (2019) .Analysis of Building Information Modeling and Scope of BIM in India. International Journal of Engineering Research \& Technology, 72-76.

[2] Rich, N. (2000). Value Analysis, Value Engineering. Cardiff, United Kingdom: Lean Enterprise Research Centre.
[3] Miles, L. D. (1972). Techniques of Value Analysis and Engineering. New York: McGraw-Hill.

[4] Attarde, N. L. (2016). Application of Value Engineering in Commercial Building Projects. International Journal of Latest Trends in Engineering and Technology (IJLTET).

[5] Ali Bagheri Fard, K. G. (2013). Evaluating Effective Factors on Value Engineering Implementation in the context of Iran. Journal of Basic and Applied Scientific Research, ISSN 2090-4304

[6] Al-Yousefi, A. S. (2011). Value engineering application benefits in Sustainable Construction. SAVE International.

[7] Senay Atabay and Niyazi Galipogullari. (2013). Application of Value Engineering in Construction Projects. Journal of Traffic and Transportation Engineering, ISSN 2328-2142, USA, pp. 39-48.

[8] Amir Shekari, F. (2009). A new approch to linking value engineering \& lean methodology. Iran: 1 9th International Conference on Production Research.

[9] Chi-Sung, Nam-kung, \& Chang-Taek Hyun. (2009). A Study on the Consecutiveness of the Function Analysis and Idea Creation Phase with Function Integration (FI) and Hierarchical Value Engineering Concept Modules (HVECM). SAVE international.

[10] Chavan, A. J. (2013, December). Value Engineering in Construction Industry. International Journal of Application or Innovation in Engineering \& Management (IJAIEM).

[11] Salman Azhar, A. N. (2008). Building Information Modeling (BIM): A New Paradigm for Visual. First International Conference on Construction in Developing Countries (ICCIDC-I). Karachi, Pakistan.

[12] Srimathi S., R. N. Uma (2017) .Implementation of BIM Tools in Construction Project. International Journal of Engineering Research \& Technology, Novermber 2017 117-120.

[13] Building SMART, N. I. (2012). National BIM Standard - United States ${ }^{\mathrm{TM}}$ Version 2. Burnside, J. (1969). Organising the V.E.-Effort in a Company. Value Engineering.

[14] Cheng Zhang, T. Z. (2016). Quantitative Assessment of Building Constructability Using BIM and 4D Simulation. Open Journal of Civil Engineering, 442-461. 